\title{
Strategies for the retention of high genetic variability in European flat oyster (Ostrea edulis) restoration programmes
}

\author{
Delphine Lallias ${ }^{a, b, ~}{ }^{*}$, Pierre Boudry ${ }^{c}$, Sylvie Lapègue ${ }^{d}$, Jon W King ${ }^{b}$, \\ Andy R Beaumont ${ }^{a, b}$
}

\begin{abstract}
a School of Ocean Sciences, College of Natural Sciences, Bangor University, Menai Bridge, Anglesey, LL59 5AB, United Kingdom

b Centre for Applied Marine Sciences, Marine Science Laboratories, Menai Bridge, Anglesey, LL59 5AB, United Kingdom

c Ifremer, UMR M100 Physiologie et Ecophysiologie des Mollusques Marins, BP 70, 29280 Plouzané, France d Ifremer, Laboratoire Génétique et Pathologie, Ronce-les-bains, 17390 La Tremblade, France

*: Corresponding author : Delphine Lallias, email address : d.lallias@bangor.ac.uk
\end{abstract}

\begin{abstract}
:
The native European flat oyster Ostrea edulis is listed in the OSPAR Convention for the Protection of the Marine Environment of the North-East Atlantic (species and habitat protection) and in the UK Biodiversity Action Plan. Once extremely abundant in the 19th century, European stocks of O. edulis have declined during the 20th century to rare, small, localised populations due to overexploitation, habitat degradation and, most recently, the parasitic disease bonamiosis. Selective breeding programmes for resistance to bonamiosis have been initiated in France and Ireland. High genetic diversity and bonamiosis-resistance would be important features of any sustainable restoration programmes for $\mathrm{O}$. edulis.
\end{abstract}

Oysters were sampled across Europe from four hatchery sources, four pond-cultured sources and four wild, but managed fisheries and were genotyped at five microsatellite loci. Hatchery-produced populations from small numbers of broodstock showed a significant loss of genetic diversity relative to wild populations and pedigree reconstruction revealed that they were each composed of a single large full-sib family and several small full-sib families. This extremely low effective population size highlights the variance in reproductive success among the potential breeders. Pond-cultured oysters were intermediate in genetic diversity and effective population size between hatchery and wild populations. Controlled hatchery production allows the development of bonamiosis-resistant strains, but at the expense of genetic diversity. Large scale pond culture on the other hand can provide a good level of genetic diversity. A mixture of these two approaches is required to ensure a healthy and sustainable restoration programme for $\mathrm{O}$. edulis in Europe.

Keywords: Restoration programme, Ostrea edulis, Genetic variation, Pedigree reconstruction 


\section{Introduction}

53

An increasing number of exploited marine species are threatened through overharvesting, habitat loss or degradation, and / or diseases (Gaffney 2006) and, as a consequence, restoration programmes are being developed. Any restoration programme should be coupled with habitat restoration / rehabilitation (McCay et al. 2003) and should attempt to restore populations that have the highest possible genetic diversity. Without sufficient genetic diversity and suitably restored habitat the long term sustainability of restored populations remains at risk.

There are three main strategies for molluscan shellfish population restoration attempts: adult transplant, juvenile seeding and larval release. Shellfish restoration projects generally focus on the second of these strategies and involve the release of hatchery-produced progenies for restocking and enhancing stocks of natural populations (Gaffney 2006; Laing et al. 2006). Gaffney (2006) reviewed the three major genetic concerns relevant to shellfish restoration projects: i) identifying source broodstock (after population genetics study at the geographical distribution scale of the species), ii) maintaining the maximum genetic variability possible and reducing inbreeding of hatchery stocks used for restoration purpose and iii) assessing the potential impact on the effective population size in wild populations of restocking with hatchery-propagated spat. Restocking with genetically improved hatchery strains could potentially have positive effects on wild populations particularly in terms of growth rate and disease resistance (Gaffney 2006). Several strategies were tested in Florida to restore and enhance populations of hard clam Mercenaria spp. (Arnold et al. 2002) and bay scallop Argopecten irradians (Arnold et al. 2005), following habitat degradation and loss. Hatchery-produced bay scallops were deployed in cages, but no significant contribution 
77 from the restoration stock to the wild population could be detected with mitochondrial

78 DNA markers (Wilbur et al. 2005). On the other hand trials of bay scallop larval release produced an increase in the scallops in the larval enclosure relative to the control enclosure (Arnold 2008).

Oyster larvae settle out of the plankton and cement themselves to hard substrates, preferentially other oyster shells. This natural process, when not disturbed by a fishery, leads to oyster reefs that can support high biodiversity in their associated community. The importance of the restoration of oyster reef habitat has been emphasised by Mann (2000) and considerable investment has been made into the restoration of reefs of the eastern cupped oyster, Crassostrea virginica, in Chesapeake Bay, USA (Brumbaugh et al. 2000). In two separate studies, four million (Milbury et al. 2004) and 0.75 million (Hare et al. 2006) C. virginica hatchery-produced spat with improved disease tolerance were planted out in 1997 and 2002 respectively on natural oyster beds in different areas of the Chesapeake Bay. The hatchery stocks could be distinguished from the wild oysters by diagnostic single nucleotide polymorphisms (SNPs) in their mitochondrial DNA, but in neither attempt was a high enhancement success detected (Milbury et al. 2004; Hare et al. 2006). Such studies on attempts at bivalve restoration from hatchery production demonstrate the importance of an evidential basis to conservation outcomes (Pullin and Knight 2009).

The native European flat oyster Ostrea edulis is listed in the OSPAR Convention for the Protection of the Marine Environment of the North-East Atlantic (species and habitat protection) and in the UK Biodiversity Action Plan and Laing et al. (2005) carried out a feasibility study for its restoration.

O. edulis is a sessile, filter-feeding bivalve mollusc with a distribution ranging from Norway to Morocco in the Atlantic Ocean, in the Mediterranean Sea and 
102 extending into the Black Sea. This species was once of huge economic importance in

103 Europe but there were massive declines in abundance in the late 1800s and early 1900s

104 probably due to overfishing, habitat deterioration and unidentified diseases. Following a

105 plateau of low level fisheries in Europe into the 1960s a further drastic decline in oyster

106 numbers occurred due to two parasitic diseases, marteiliosis (Marteilia refringens),

107 mainly affecting estuarine populations, and the more serious bonamiosis (Bonamia

108 ostreae) that causes heavy mortalities in both intertidal and subtidal areas.

109 Selective breeding programmes for resistance to bonamiosis have been initiated

110 in France (Naciri-Graven et al. 1998) and Ireland (Culloty et al. 2004) and have

111 demonstrated an important potential for genetic gain through selective breeding.

112 Additionally, significant differences in growth, mortality and susceptibility to

113 bonamiosis and other diseases were observed between geographic origins and between

114 families (da Silva et al. 2005). More recently, quantitative trait loci (QTLs) linked to

115 bonamiosis resistance have been mapped (Lallias et al. 2009) and the search for

116 candidate genes involved in the resistance to bonamiosis has been initiated (Morga et al.

117 Unpublished results). Such studies highlight the possibilities of restoring flat oyster

118 populations by restocking with hatchery-produced bonamiosis-resistant seed.

119 Before implementing such restoration programmes in O. edulis, it is important to

120 assess the potential impact of hatchery-propagated stocks on the genetic variability and

121 the effective population size of wild populations (Gaffney 2006). Several studies have

122 reported the loss of genetic diversity and a reduced effective population size in hatchery

123 populations of shellfish, particularly oysters (Gosling 1982; Hedgecock and Sly 1990;

124 Gaffney et al. 1992; Hedgecock et al. 1992; Saavedra and Guerra 1996; Saavedra 1997;

125 Launey et al. 2001; Boudry et al. 2002; Sobolewska and Beaumont 2005; Appleyard

126 and Ward 2006; Taris et al. 2007; Lind et al. 2009). So, while hatchery production is an 
127 effective method to produce large numbers of seed for restoration, and controlled

128 conditions allow the development of disease resistant strains, its major drawback is the 129 loss of genetic diversity.

130 The earliest method for artificial oyster production was the use of large ponds

131 that were seeded with hundreds of adult oysters and the resultant spat collected on shells

132 or tiles placed in the pond. Ponds were originally crude un-lined basins 2-3 m deep and

133 up to 10 hectares in area. Natural ponds or "polls" were exploited in parts of Norway

134 that enabled enhanced spat production by making use of the greenhouse effect of a layer

135 of surface fresh water (Kirkland et al. 1983). Ponds fell out of favour in the 1960s when

136 hatchery culture proved to be more controlled and more reliable, but recently smaller

137 replicated butyl-lined ponds have been revived and have proved to be a reliable source

138 of oyster spat production (Gathorne-Hardy and Hugh-Jones 2004; Laing et al. 2005).

139 However, there are no published data on the potential loss of genetic diversity inherent

140 in pond production.

141 Traditionally, natural recruitment from wild populations was encouraged by the

142 laying of tiles or shells to collect oyster spat. Young oysters were then scraped from the

143 tiles and re-seeded into the fishery. This enhancement of natural recruitment by

144 providing abundant settlement substrate would be expected to maintain existing genetic 145 variability.

146 In the present study we have used $O$. edulis supplied from hatchery culture, pond

147 culture and from natural recruitment to compare the genetic diversity at highly variable

148 microsatellite loci generated by these three types of seed sources. Such information is

149 critical to any proposed restoration programme for this species in Europe.

151 2. Materials and methods 


\subsection{Sampling}

Twelve O. edulis populations were sampled (Figure 1). Between 30 and 48 oysters per population were analysed.

The wild or managed populations were sampled in in Loch Ryan (Scotland, WLR) in 2006; in Quiberon (France, WQ) and Grevelingen (the Netherlands, WGr) in 2007; and in Ria Formosa (Portugal, WRF) in 2008. Quiberon, a large bay in southern Brittany, is a major site of flat oyster spat collection and on-growing. Grevelingen is a landlocked population, in a shallow (2-10 m) marine lake. Over-exploitation of its stocks lead to successive importations of foreign spat (MacKenzie et al. 1997). Since

163 1964, no commercial production and no foreign importations have been reported for

164 Grevelingen oysters (Drinkwaard 1999). Ria Formosa is a shallow coastal lagoon located in Algarve (southern Portugal). The clam Ruditapes decussatus and the cupped oysters Crassostrea gigas and Crassostrea angulata are farmed in this site (Chícharo and Chícharo 2001) but flat oysters are not sufficiently abundant for commercial exploitation (Batista, Personal communication). The Loch Ryan population represents a long-managed wild stock with regular natural spatfall and is the largest fishery for native oysters in Scotland (Hugh-Jones 2003). Oysters from France, Holland or Essex were laid in Loch Ryan in 1880s and in 1960s (Beaumont et al. 2006). The pond-produced populations were sampled in Boemlo (Norway, PBo),

173 Vaagstranda (Norway, PVa), Venø (Denmark, PVe) in 2007 and in Rossmore (Ireland, 174 PRo) in 1999. In Norway two types of ponds (heliothermic polls) are traditionally used 175 for cultivation (Kirkland et al. 1983; MacKenzie et al. 1997). The "breed-polls", 5-10 $176 \mathrm{~m}$ deep, 1-5 ha in area, exhibit strong salinity stratification, have restricted water 
177 exchange with the outside fjord (tidal exchanges controlled by a gate) and are used for

178 spawning and collecting spat. The "spat-polls", larger (up to $20 \mathrm{~m}$ deep and 40 ha in

179 area), exchange water with the outside fjord and are used as fattening grounds

180 (MacKenzie et al. 1997). The Boemlo population (Boemlo Skjell Ltd) was sampled

181 from a "breed-poll" of 2 ha, 5-6 m deep, containing around 2500 oysters, the

182 broodstock originating in the 1980s from a mixture of different populations around

183 Norway (Magnesen, Personal communication). The Vaagstranda population (Arctic

184 Oysters Ltd) was sampled from a "spat-poll" of 40 ha, 10-12 m deep, containing

185100000 oysters which originated from an introduction from Holland in 1930

186 (Magnesen, Personal communication). The Danish Venø population was produced in

1872004 in outdoor ponds (about 0.07 ha, $1.7 \mathrm{~m}$ deep) containing 400 oysters originated

188 from Limfjord (Nissum Bredning) (Ommaney, Personal communication). The

189 Rossmore population (Cork Harbour) was produced in the context of selective breeding

190 programme for resistance to bonamiosis: oysters were bred in spatting ponds from older

191 oysters that survived the epizooty or were resistant to $B$. ostreae and that have been

192 selectively bred for several generations (Sobolewska and Beaumont 2005). The

193 Rossmore pond production was based on 22 butyl-lined ponds (0.04 ha, $2 \mathrm{~m}$ deep).

194 These ponds were stocked with up to 700-800 oysters (Laing et al. 2005; Gathorne-

195 Hardy and Hugh-Jones 2004).

196 The hatchery-produced populations were derived either from a commercial

197 hatchery (Seasalter Shellfish Ltd, Whitstable, England) or from a research hatchery

198 (Ifremer, Argenton, France). The Loch Kishorn population (Scotland, HLK), sampled in

199 2000, originated from Seasalter hatchery (original seed) (Sobolewska and Beaumont

200 2005). The Orkney population (Scotland, HO), sampled in 2000, was three generations

201 removed from original Seasalter seed (Sobolewska and Beaumont 2005). The HBOR 
202 population resulted from the mixing of two spawning events $(11 / 06 / 2007$ and

203 27/06/2007) from 58 Bonamia ostreae-resistant broodstock originating from the French

204 selective breeding programme (Naciri-Graven et al. 1998). The HMED population

205 resulted from the mixing of two spawning events (09/06/2007 and 22/06/2007) from 95

206 wild Mediterranean oysters from Thau lagoon.

207

\subsection{DNA extraction and amplification of microsatellite loci}

209

210

Genomic DNA was extracted from gill tissue, using a standard chloroform /

211 isoamylalcohol method (Sambrook et al. 1989) and purified with the Wizard DNA

212 Clean Up System (Promega). DNA quantification was performed using a

213 spectrophotometer (BioPhotometer, Eppendorf). Five microsatellite markers were amplified following the authors' instructions: OeduJ12, OeduT5 (Launey et al. 2002);

Oedu.B11 (Naciri et al. 1995); Oedu.HA7 (Sobolewska et al. 2001) and Oe3/44

216 (Morgan et al. 2000). OeduT5 and Oedu.HA7 are distributed in the same linkage group,

217 OeduJ12, Oedu.B11 and Oe3/44 being distributed on three different linkage groups

218 (Lallias et al. 2007).

219

\subsection{Genetic analysis}

221

Genetic diversity within each of the twelve populations was measured as the number of alleles per locus $\left(N_{a}\right)$, the observed heterozygosity $\left(H_{o}\right)$ and unbiased expected heterozygosity $\left(H_{e}\right)(\mathrm{Nei} 1978)$ under Hardy-Weinberg equilibrium. Allelic richness $(A)$ (correcting frequency for unequal sample sizes) (El Mousadik and Petit 1996) was estimated per locus and per sample. All analyses were performed with 
227 FSTAT ver. 2.9 (Goudet 1995). Allelic richness and expected heterozygosity were

228 compared between the three groups (wild, pond, hatchery) using a one-way ANOVA

229 marker by marker followed by Tukey's pairwise comparisons, or a Kruskall-Wallis test

230 when variances were not equal (PAST software, Hammer et al. 2001). Wright's (1931)

231 F-statistics were computed according to Weir and Cockerham's (1984) estimators, using

232 FSTAT. Deviations from Hardy-Weinberg equilibrium $\left(\mathrm{F}_{\mathrm{is}}\right)$ were computed in each

233 sampled population and genetic differentiation between populations was estimated

234 using Wright's fixation index $F_{\text {st }}$. The significance of departure from zero of $F_{\text {is }}\left(\right.$ or $\left.F_{\text {st }}\right)$

235 values was assessed by randomizing alleles within samples (or genotypes among

236 samples), based on 2000 randomizations and after Bonferroni adjustment.

\subsection{Linkage disequilibrium analysis}

239

Linkage disequilibrium was assessed by permutation tests ( 1000 permutations) with GENETIX 4.1 software (Belkhir et al. 1996-2001), for each pair of markers in each population.

\subsection{Estimation of effective breeding sizes}

Effective breeding sizes $\left(N_{b}\right)$ were estimated for the 12 populations sampled

247 using three different methods. The heterozygote excess method was implemented in

248 Colony v2.0 (Wang 2009). The linkage disequilibrium method (Hill 1981) was

249 implemented in LDNE program (Waples and Do 2008). For this method, the lowest

250 allele frequency used ( $\mathrm{P}_{\text {crit }}$ value) was 0.02 , as recommended by Waples and Do (2009).

251 Sibship-based estimates were obtained using Colony v2.0 (Wang 2009), assuming a 
252 polygamous breeding system for males and females, and using the full likelihood model

253 with medium precision and no prior information. Also, Spearman rank correlations $\left(\mathrm{r}_{\mathrm{s}}\right)$

254 were calculated between $N_{b}$ estimates and allelic richness.

255

\subsection{Pedigree reconstruction analysis}

Pedigree reconstruction on the four hatchery-produced populations was

performed with PEDIGREE 2.2 (Herbinger et al. 2006), which partitions individuals into family groups (full-sibs (FS) or half-sibs (HS)) based on molecular marker data in the absence of parental information. Four parameters are chosen by the user: number of

262 iterations of the Markov Chain, full-sib constraint (to choose between a full-sib partition and a kin group partition), temperature of the Markov Chain and weight (W) used in computing the partition score.

The four hatchery datasets were analysed with the FS partition algorithm in

266 order to detect the presence of FS families. To generate the best (with the highest score)

267 full-sibs partition with $\mathrm{W}=1$, we performed four runs with 1 million iterations and temperature of 10 , followed by four runs with 1 million iterations and temperature of 30 and used the best FS partition $\mathrm{W}=1$ as a start-up partition file to check that no better partition could be found. This procedure was repeated with $\mathrm{W}=5$ and $\mathrm{W}=10$. The three

271 best FS partitions obtained with an increasing weight were then compared with the

272 COMPARE function of PEDIGREE 2.2.

273

274

3. Results

275

276

\subsection{Linkage disequilibrium}


No significant linkage disequilibrium was observed for the four wild populations and PVa. Significant linkage disequilibrium was observed for PBo (1 out of 10 pairs), PRo (5 out of 10 pairs), PVe and HO (6 out of 10 pairs), HBOR (8 out of 10 pairs), HLK and HMED (all 10 pairs of loci).

\subsection{Comparison of genetic diversity between wild, pond and hatchery populations}

allelic richness (averaged over 5 loci and 4 populations) was 7.57 for the hatcheryderived populations, 14.07 for the pond-produced populations and 18.43 for the wild populations. One-way ANOVA performed for each marker revealed that, at each locus, hatchery-derived populations exhibited a significantly lower mean allelic richness than the pond-derived and the wild populations $(\mathrm{p}<0.05)$. For three out of five loci significantly lower $(\mathrm{p}<0.05)$ allelic richness than the wild populations. Mean observed heterozygosity varied between $0.756(\mathrm{PBo})$ and $0.856(\mathrm{HBOR})$ and mean expected heterozygosity ranged from 0.680 (HMED) to 0.915 (WLR) (Table 1). Mean expected heterozygosity (averaged over 5 loci and 4 populations) was $0.743,0.857$ and 0.900 for hatchery-produced, pond-produced, and wild populations respectively. For four out of

297 five loci (all but Oe3/44), one-way ANOVA revealed that hatchery derived populations 298 exhibited significantly lower expected heterozygosities than pond derived populations and wild populations ( $\mathrm{p}<0.05$ for each pairwise comparison). Wright's (1965) $\mathrm{F}_{\text {is }}$ calculated for all five loci in each population showed significant overall heterozygote deficiencies for four populations (WQ, WGr, WLR and 
302 PBo) after Bonferroni adjustment ( $<<0.05$ ), mainly due to locus Oedu.B11 (Table 1).

303 Null alleles were suspected at that locus. After the removal of locus Oedu.B11 from the

304 analyses, no significant deficiencies of heterozygotes were observed. Significant

305 heterozygote excesses were observed for two of the hatchery populations (HBOR and

306 HMED) (p<0.05 after Bonferroni adjustment) (Table 1) for all markers. Finally, the four

307 hatchery populations exhibited a significant overall excess of heterozygotes $(\mathrm{p}<0.05)$

308 after the removal of locus Oedu.B11 (Table 1).

309

\subsection{Genetic differentiation among populations}

$\mathrm{F}_{\mathrm{st}}$ values for pairwise comparison among populations from $O$. edulis are given

313 in Table 2 . Among the wild populations, $F_{\text {st }}$ values were low, ranging from 0.006 to

3140.044 . Only the Grevelingen population was significantly differentiated from the

315 Quiberon and the Ria Formosa populations. Pond and hatchery-produced populations

316 were significantly differentiated from each other and from the wild populations $\left(\mathrm{F}_{\mathrm{st}}\right.$

317 values ranging from 0.006 to 0.254 ). HMED was the population exhibiting the highest

$318 \mathrm{~F}_{\mathrm{st}}$ values (from 0.126 to 0.254 ) in the pairwise comparison with the other populations.

\subsection{Effective breeding sizes}

$N_{b}$ estimates for the 12 O. edulis populations are shown in Table 3 . The

323 heterozygote excess method only generated $N_{b}$ estimates for two hatchery populations,

324 HBOR (7) and HMED (7), without 95\% confidence intervals. With the linkage

325 disequilibrium (LD) method, very high effective breeding sizes were obtained for the

326 four wild populations and two Norwegian pond-produced populations (PBo and PVa) 


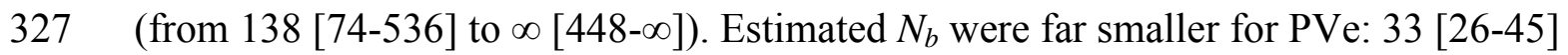
and PRo: 49 [37-70]. For the hatchery-produced populations, relatively small $N_{b}$ were reported for HO: 19 [14-25]; and very small $N_{b}$ for HBOR: 6 [3-10], HLK: 4 [3-8] and HMED: 2 [2-3]. By contrast, the sibship assignment (SA) - based method produced $N_{b}$ estimates and finite $95 \%$ confidence intervals for the 12 sampled populations. Both LD and SA methods gave similar $N_{b}$ estimates for six populations: the two small pondproduced and the four hatchery-produced populations. However, for the two large pondproduced and the four wild populations, the SA method produced far smaller $N_{b}$ estimates than the LD method. Figure 2 shows significant positive correlations between the two $N_{b}$ estimates and allelic richness in the 12 flat oyster populations $\left(\mathrm{r}_{\mathrm{s}}(\mathrm{LD})=\right.$ $\left.0.869, \mathrm{P}<0.001 ; \mathrm{r}_{\mathrm{S}}(\mathrm{SA})=0.931, \mathrm{P}<0.001\right)$

\subsection{Pedigree reconstruction analysis}

For the HMED population, the best FS partition (score 3924.03, W=5) identified

3428 groups (Figure 3). We were able to reconstruct the parental genotypes of the large FS

343 family (30 offspring) and calculate segregation distortion amongst the progeny (Table 344 4).

The best FS partition (score $1576.25, \mathrm{~W}=5$ ) revealed 8 groups in the HBOR

346 population (Figure 3). The parental genotypes of the two largest FS families could be

347 reconstructed and were identical at four out of five loci. Differences between them

348 occurred only at the Oedu.B11 locus. The parental Oedu.B11 genotypes of the first 349 family were $122 / 122 \times 122 / 166$ but were $128 / 128 \times 128 / 166$ for the second family. Four 350 different genotypes were present among the progeny of the two first families: $128 / 166$, $351128 / 128,122 / 166$ and 122/122. Therefore, this was compatible with the segregation of a 
null allele (Table 5). We concluded that the two largest FS families (18 and 12 offspring

353 respectively) in this HBOR population were in fact a single FS family of 30 offspring

354 (Figure 3, Table 4).

For the HLK population, the best FS partition (score 1796.43; W=10) identified

3567 groups (Figure 3). After reconstructing the parental genotypes of the largest FS family

357 containing 14 offspring, it was noted that a separate group of four offspring could be

358 placed within that FS family if an Oedu.B11 null allele was present in one parent (Table

359 5). Therefore, we concluded that the largest FS family in the HLK sample consisted of

36018 offspring (Figure 3, Table 4).

Finally, the HO population revealed (score 3759.14, W=5) 16 groups (Figure 3).

362 By changing $\mathrm{W}$ from 5 to 10 some groups with one or two offspring merged with other

363 small FS groups. Parental genotypes could not be reconstructed for any FS family.

364 Therefore the HO population appeared to be composed of several small FS families, in contrast to the HMED, HBOR and HLK populations.

\section{Discussion}

\subsection{Loss of genetic diversity} comparison with pond-produced and wild populations, both in terms of a reduction in allelic richness and in the expected heterozygosity. Pond-produced populations were quite effective in maintaining the genetic diversity but small scale ponds still showed a significant reduction in allelic richness relative to wild populations. These results are not surprising because reduced genetic diversity has been reported in hatchery or 
aquaculture populations of finfish (Bouza et al. 1997; Lundrigan et al. 2005; Liu et al. 2005; Machado-Schiaffino et al. 2007), algae (Guillemin et al. 2008) and shellfish

379 (Gaffney et al. 1992; Hedgecock et al. 1992; Saavedra 1997; Taris et al. 2006; Hara and

380 Sekino 2007; Lind et al. 2009). However, we are able to demonstrate that alternative

381 managed reproduction methods using large scale ponds can retain high genetic diversity

382 in the flat oyster and that this information is of significant value for restoration of this

383 species.

384

385

4.2. High variance in reproductive success and small effective breeding size

$N_{b}$ estimates were obtained based on different methods (Table 3). As reported by Beebee (2009) and Wang (2009), the heterozygote excess method performed very badly and gave meaningful estimates for only 2 (out of 12) populations. The linkage disequilibrium (LD) and sibship assignment (SA) methods gave consistent $N_{b}$ estimates for six populations (the four hatchery and the two small pond populations), bolstering confidence in our results. However, the SA method gave far smaller $N_{b}$ estimates

393 (below 70), compared with the LD method (between 138 and infinity), for the two large pond and the four wild populations. The low number of markers used in this study, as well as a sample size much smaller than the actual effective population size could explain the discrepancies in the $N_{b}$ estimates. Indeed, in such a situation, the SA method

397 becomes biased and yields confidence intervals that are too narrow (Wang 2009). Also,

398 the SA method assumes sampling from a single cohort; violation of this assumption could have an impact on $N_{b}$ estimates. The LD-based $N_{b}$ estimates, although less precise, seem therefore to give more realistic estimates in our study. Despite the slight

401 discrepancies in the $N_{b}$ estimates, allelic richness analyses and $N_{b}$ estimates gave 
consistent results: significant positive correlations between LD-based or SA-based $N_{b}$

403 estimates and allelic richness were observed (Figure 2). This is in agreement with the 404 neutral theory that predicts a positive, albeit nonlinear, relationship between $\ln N_{e}$ and genetic diversity (Soulé 1976). Such a linear correlation has previously been shown by Beebee (2009) in toad populations.

Our results revealed that the four hatchery populations had much reduced

408 effective breeding sizes compared with wild and pond populations (Table 3). Also, the occurrence of heterozygote excesses in the hatchery populations (Table 1) could be a consequence of low $N_{b}$ (Luikart and Cornuet 1999). HLK and HO populations both originated from Seasalter hatchery, the HLK oysters being first generation while the HO oysters are 3 generations removed from Seasalter imports. Interestingly $\mathrm{HO}$ was associated with a higher $N_{b}$ than HLK. Following a hatchery bottleneck, the linkage disequilibrium is expected to decay over time (assuming random mating of hatcheryproduced oysters after the bottleneck), with a consequent increase in $N_{b}$ estimate. However, hatchery bottlenecks are likely to vary in their strength even within the same

417 hatchery. Therefore, it would be best to make temporal comparisons of $N_{b}$ estimates to 418 assess the within-hatchery variance, before drawing conclusions about the long term consequences of hatchery practices.

The negative impacts on genetic diversity of hatchery practices such as mass spawning, culling of slow-growing larvae (Taris et al. 2006) or communal rearing of different families have been widely documented. In particular, the impact in terms of a 423 reduced $N_{b}$ has been previously reported for many shellfish species (e.g. Hedgecock et al. 1992), and oysters in particular: the pearl oyster Pinctada maxima (Lind et al. 2009); the cupped oysters Crassostrea gigas and C. virginica (e.g. Hedgecock and Sly 1990;

426 Gaffney et al. 1992; Appleyard and Ward 2006) and the flat oyster O. edulis (e.g. 
427 Saavedra and Guerra 1996; Saavedra 1997; Launey et al. 2001). Some remediation of

428 the problem can be achieved by pooling the progeny of multiple spawning events

429 (Gaffney et al. 1992) or by performing controlled spawnings (Lind et al. 2009).

430 However, flat oysters are sequential hermaphrodites and an individual's sex at any time

431 cannot be determined non-destructively. A further complication is that males produce

432 spermatozeugmata and females brood their eggs and early larvae up to approximately

43310 days after fertilization (O'Foighil 1989) adding to the difficulty of making controlled

434 multiple crosses or mass matings. We know that two hatchery populations used in our

435 study (HBOR and HMED) involved the pooling of two spawning events but they still

436 had a very low effective breeding size (below 6 or 12 according to the LD and SA

437 methods respectively). Even at the small pond scale (Venø, Rossmore), where 400-800

438 broodstock were used, there was a reduced $N_{b}$ although more genetic diversity was

439 retained than the hatchery-produced populations. Therefore, simply increasing the

440 number of breeders does not necessarily increase the effective breeding size. It is only

441 when we move to the Norwegian ponds of larger dimensions that LD-based $N_{b}$

442 approaches that of the wild populations. In such ponds, the oyster population remains

443 undisturbed from year to year, allowing spatial dynamics such as clumping to develop

444 among breeders, which may affect $N_{b}$. This does not happen in small ponds (such as

445 PRo) because they are emptied and cleaned each year.

446 Pedigree reconstruction of the four hatchery-produced populations revealed that

447 three of those populations (HMED, HBOR, and HLK) were composed of a large full-sib

448 family and a few small full-sib families. Pedigree reconstruction and $N_{b}$ estimation gave

449 congruent results: HMED is the hatchery population with the lowest $N_{b}$ and with the

450 highest skew in family contribution, while HO is the hatchery population with the

451 highest $N_{b}$ and the highest number of contributing families as well as a more even 
452 contribution of families (Table 3, Figure 3). This also strongly highlights the variance in

453 reproductive success among the potential breeders, something that has also been

454 demonstrated for salmonids (Herbinger et al. 2006). High relatedness among progenies,

455 as demonstrated by our pedigree reconstruction analyses, could have serious

456 implications for the long-term management of hatchery stocks, rapidly leading to

457 inbreeding depression (Bierne et al. 1998; Naciri-Graven et al. 2000; Taris et al. 2007)

458 due to a high genetic load in oysters (Launey and Hedgecock 2001). Recent studies

459 reported high variance of reproductive success in oysters both in the wild (Li and

460 Hedgecock 1998; Hedgecock et al. 2007) and under aquaculture conditions (Hedgecock

461 et al. 1992; Boudry et al. 2002; Taris et al. 2007; Lallias et al. Unpublished results).

462 Variance in reproductive success seems a fundamental factor influencing the $N_{b}$.

463 Therefore, further studies should be implemented to improve hatchery practices, in

464 order to reduce variance in family contributions.

465

\subsection{Implications for restoration}

467

Hatchery-produced populations of oysters are associated with a significant loss of allelic diversity and heterozygosity. Moreover, almost no genetic differentiation was observed across the wild populations (as shown by Launey et al. 2002; Sobolewska and Beaumont 2005; Beaumont et al. 2006), whereas hatchery practices led the hatchery-

472 produced populations to be highly differentiated from the wild populations (Table 2).

473 Unless hatcheries significantly change their methods of production, the restoration of wild populations of $O$. edulis by hatchery-produced stocks could be detrimental to the conservation of oysters and the long-term sustainability of their fisheries. Further 
477 better estimate the potential impacts and benefits of supportive breeding (Ryman and

478 Laikre 1991; Gaffney 2006). There is little sense in mounting a major restoration

479 programme for flat oysters if it will not lead to increased population sizes of wide

480 genetic diversity. Genetic diversity is essential for long term sustainability. Large scale

481 pond-production systems could represent a valuable alternative to hatcheries for

482 restocking flat oyster populations because they seem more efficient in the maintaining

483 of genetic diversity.

484 Restoration of flat oyster populations in Europe is complicated by the existence

485 of bonamiosis which can cause very high mortalities in flat oyster populations. At the

486 present time, some areas in northern Europe are bonamiosis-free while the disease is

487 common elsewhere. Restoration of oysters in bonamiosis-free regions could therefore

488 take advantage of the potential high genetic diversity provided by large scale pond

489 production. In bonamiosis areas the better strategy might be to attempt restoration using

490 bonamiosis-resistant strains from hatchery (Naciri-Graven et al. 1998) or small pond-

491 culture (Culloty et al. 2004) but to also to improve hatchery and small pond production

492 methods to gain the highest genetic diversity possible.

493

494 Acknowledgements

495

496 We would like to thank Thorolf Magnesen for supplying the two Norwegian oyster

497 populations, Alexandra Leitão for the Ria Formosa population, and René Robert for the

498 French hatchery HBOR and HMED samples. We thank two anonymous reviewers for

499 useful comments and suggestions. This research has been financed by the European

500 Regional Development Fund INTERREG IIIB Priority C, project 201 - AAAG2

501 (Atlantic Arc Aquaculture Group 2). 


\section{References}

Appleyard SA, Ward RD (2006) Genetic diversity and effective population size in mass selection lines of Pacific oyster (Crassostrea gigas). Aquaculture 254:148-159.

Arnold WS (2008) Application of Larval Release for Restocking and Stock Enhancement of Coastal Marine Bivalve Populations. Rev Fish Sci 16:65 - 71.

Arnold WS, Marelli DC, Parker M, Hoffman P, Frischer M, Scarpa J (2002) Enhancing hard clam (Mercenaria spp.) population density in the Indian River Lagoon, Florida: a comparison of strategies to maintain the commercial fishery. J Shellfish Res

Arnold WS, Blake NJ, Harrison MM, Marelli DC, Parker ML, Peters SC, Sweat DE (2005) Restoration of bay scallop (Argopecten irradians (Lamarck)) populations in

Beaumont AR, Trebano Garcia M, Honig S, Low P (2006) Genetics of Scottish populations of the native oyster, Ostrea edulis: gene flow, human intervention and conservation. Aquat Living Resour 19:389-402.

Beebee TJC (2009) A comparison of single-sample effective size estimators using empirical toad (Bufo calamita) population data: genetic compensation and population size-genetic diversity correlations. Mol Ecol 18:4790-4797. logiciel sous Windows TM pour la génétique des populations. Montpellier, France : Montpellier II. 
527 Bierne N, Launey S, Naciri-Graven Y, Bonhomme F (1998) Early effect of inbreeding

528 as revealed by microsatellite analyses on Ostrea edulis larvae. Genetics 148:1893-

$529 \quad 1906$.

530 Boudry P, Collet B, Cornette F, Hervouet V, Bonhomme F (2002) High variance in

531 reproductive success of the Pacific oyster (Crassostrea gigas, Thunberg) revealed

532 by microsatellite-based parentage analysis of multifactorial crosses. Aquaculture

$533 \quad 204: 283-296$.

534 Bouza C, Sanchez L, Martinez P (1997) Gene diversity analysis in natural populations and cultured stocks of turbot (Scophthalmus maximus L.). Anim Genet 28:28-36.

536 Brumbaugh RD, Sorabella LA, Garcia CO, Goldsborough WJ, Wesson JA (2000)

537 Making a case for community-based oyster restoration: An example from Hampton

538 Roads, Virginia, U.S.A. J Shellfish Res 19:467-472.

539 Chícharo L, Chícharo MA (2001) Effects of environmental conditions on planktonic

540 abundances, benthic recruitment and growth rates of the bivalve mollusc Ruditapes

541 decussatus in a Portuguese coastal lagoon. Fish Res 53:235-250.

542 Culloty SC, Cronin MA, Mulcahy MF (2004) Potential resistance of a number of

543 populations of the oyster Ostrea edulis to the parasite Bonamia ostreae. Aquaculture $544 \quad 237: 41-58$.

545 da Silva PM, Fuentes J, Villalba A (2005) Growth, mortality and disease susceptibility

$546 \quad$ of oyster Ostrea edulis families obtained from brood stocks of different

547 geographical origins, through on-growing in the Ría de Arousa (Galicia, NW Spain).

$548 \quad$ Mar Biol 147:965-977.

549 Drinkwaard A (1999) Introductions and developments of oysters in the North Sea area:

$550 \quad$ A review. Helgol Meeresunters 52:301-308. 
551 El Mousadik A, Petit RJ (1996) High level of genetic differentiation for allelic richness 552 among populations of the argan tree [Argania spinosa (L.) Skeels] endemic to $553 \quad$ Morocco. Theor Appl Genet 92:832-839.

554 Foighil DO (1989) Role of spermatozeugmata in the spawning ecology of the brooding $555 \quad$ oyster Ostrea edulis. Gamete Res 24:219-228.

556 Gaffney PM (2006) The role of genetics in shellfish restoration. Aquat Living Resour $557 \quad 19: 277-282$.

558 Gaffney PM, Davis CV, Hawes RO (1992) Assessment of drift and selection in 559 hatchery populations of oysters (Crassostrea virginica). Aquaculture 105:1-20.

560 Gathorne-Hardy A, Hugh-Jones T (2004) Spat collection in native oyster ponds.

$561 \quad$ Shellfish News 17:6-9.

562 Gosling EM (1982) Genetic variability in hatchery-produced Pacific oysters

563 (Crassostrea gigas Thunberg). Aquaculture 26:273-287.

564 Goudet J (1995) FSTAT (vers. 1.2): a computer program to calculate F-statistics. J $565 \quad$ Hered 86:485-486

566 Guillemin ML, Faugeron S, Destombe C, Viard F, Correa JA, Valero M (2008) Genetic 567 variation in wild and cultivated populations of the haploid-diploid red alga 568 Gracilaria chilensis: how farming practices favor asexual reproduction and 569 heterozygosity. Evolution 62:1500-1519.

570 Hammer Ø, Harper DAT, Ryan PD (2001) PAST: Palaeontological Statistics software 571 package for education and data analysis. Palaeontologia Electronica 4, 9 pp.

572 Hara M, Sekino M (2007) Genetic Differences Between Hatchery Stocks and Natural 573 Populations in Pacific Abalone (Haliotis discus) Estimated Using Microsatellite $574 \quad$ DNA Markers. Mar Biotech 9:74-81. 
Hare MP, Allen SK, Bloomer P, Camara MD, Carnegie RB, Murfree J, Luckenbach M, Meritt D, Morrison C, Paynter K, Reece KS, Rose CG (2006) A genetic test for recruitment enhancement in Chesapeake Bay oysters, Crassostrea virginica, after population supplementation with a disease tolerant strain. Conserv Genet 7:717-734.

Hedgecock D, Sly F (1990) Genetic drift and effective population sizes of hatcherypropagated stocks of the Pacific oyster, Crassostrea gigas. Aquaculture 88:21-38.

Hedgecock D, Chow V, Waples RS (1992) Effective population numbers of shellfish broodstocks estimated from temporal variance in allelic frequencies. Aquaculture $108: 215-232$

Hedgecock D, Launey S, Pudovkin AI, Naciri Y, Lapègue S, Bonhomme F (2007) Small effective number of parents $\left(\mathrm{N}_{\mathrm{b}}\right)$ inferred for a naturally spawned cohort of juvenile European flat oysters Ostrea edulis. Mar Biol 150:1173-1182.

Herbinger CM, O'Reilly PT, Verspoor E (2006) Unravelling first-generation pedigrees in wild endangered salmon populations using molecular genetic markers. Mol Ecol $15: 2261-2275$.

Hill WG (1981) Estimation of effective population size from data on linkage disequilibrium. Genet Res 38:209-216.

Hugh-Jones T (2003) The Loch Ryan native oyster fishery. Shellfish News 15:17-18.

Kirkland DW, Platt Bradbury J, Dean WE (1983) The heliothermic lake - a direct method of collecting and storing solar energy. Arch Hydrobiol 65:1-60.

Laing I, Walker P, Areal F (2005) A feasibility study of the native oyster (Ostrea edulis) stock regeneration in the United Kingdom (CARD Project Report FC1016). Available via DIALOG. http://www.defra.gov.uk/science/project_data/DocumentLibrary/FC1016/FC1016_2 543_FRP.pdf. 
600 Laing I, Walker P, Areal F (2006) Return of the native - is European oyster (Ostrea

601 edulis) stock restoration in the UK feasible? Aquat Living Resour 19:283-287.

602 Lallias D, Beaumont AR, Haley CS, Boudry P, Heurtebise S, Lapègue S (2007) A first-

603 generation genetic linkage map of the European flat oyster Ostrea edulis (L.) based

604 on AFLP and microsatellite markers. Anim Genet 38:560-568.

605 Lallias D, Gomez-Raya L, Haley C, Arzul I, Heurtebise S, Beaumont A, Boudry P,

606 Lapègue S (2009) Combining Two-Stage Testing and Interval Mapping Strategies

607 to Detect QTL for Resistance to Bonamiosis in the European Flat Oyster Ostrea

$608 \quad$ edulis. Mar Biotechnol 11:570-584.

609 Launey S, Hedgecock D (2001) High genetic load in the Pacific oyster Crassostrea

$610 \quad$ gigas. Genetics 159:255-265.

611 Launey S, Barre M, Gerard A, Naciri-Graven Y (2001) Population bottleneck and

612 effective size in Bonamia ostreae-resistant populations of Ostrea edulis as inferred

613 by microsatellite markers. Genet Res 78:259-270.

614 Launey S, Ledu C, Boudry P, Bonhomme F, Naciri-Graven Y (2002) Geographic

615 structure in the European flat oyster (Ostrea edulis L.) as revealed by microsatellite

616 polymorphism. J Hered 93:331-351.

617 Li G, Hedgecock D (1998) Genetic heterogeneity, detected by PCR-SSCP, among

618 samples of larval Pacific oysters (Crassostrea gigas) supports the hypothesis of

619 large variance in reproductive success. Can J Fish Aquat Sci 55:1025-1033.

620 Lind CE, Evans BS, Knauer J, Taylor JJU, Jerry DR (2009) Decreased genetic diversity

621 and a reduced effective population size in cultured silver-lipped pearl oysters

622 (Pinctada maxima). Aquaculture 286:12-19.

623 Liu Y, Chen S, Li B (2005) Assessing the genetic structure of three Japanese flounder

624 (Paralichthys olivaceus) stocks by microsatellite markers. Aquaculture 243:103-111. 
625 Luikart G, Cornuet JM (1999) Estimating the effective number of breeders from

626 heterozygote excess in progeny. Genetics 151:1211-1216.

627 Lundrigan TA, Reist JD, Ferguson MM (2005) Microsatellite genetic variation within

628 and among Arctic charr (Salvelinus alpinus) from aquaculture and natural

629 populations in North America. Aquaculture 244:63-75.

630 Machado-Schiaffino G, Dopico E, Garcia-Vazquez E (2007) Genetic variation losses in 631 Atlantic salmon stocks created for supportive breeding. Aquaculture 264:59-65.

632 MacKenzie CL, Burrel VG, Rosefield A, Hobart WL (1997) The history, present

633 condition, and future of the molluscan fisheries of north and central America and

634 Europe. National Marine Fisheries Service, Washington, DC.

635 Mann R (2000) Restoring the oyster reef communities in the Chesapeake bay: a

636 commentary. J Shellfish Res 19:335-339.

637 McCay DPF, Peterson CH, DeAlteris JT, Catena J (2003) Restoration that targets

638 function as opposed to structure: replacing lost bivalve production and filtration.

$639 \quad$ Mar Ecol Prog Ser 264:197-212.

640 Milbury C, Meritt D, Newell R, Gaffney P (2004) Mitochondrial DNA markers allow

641 monitoring of oyster stock enhancement in the Chesapeake Bay. Mar Biol 145:351-

642359.

643 Morgan TS, Rogers AD, Iyengar A (2000) Novel microsatellite markers for the

$644 \quad$ European oyster Ostrea edulis. Mol Ecol 9:495-497.

645 Naciri-Graven Y, Martin A-G, Baud J-P, Renault T, Gerard A (1998) Selecting the flat

646 oyster Ostrea edulis (L.) for survival when infected with the parasite Bonamia

$647 \quad$ ostreae. J Exp Mar Biol Ecol 224:91-107. 
648 Naciri-Graven Y, Launey S, Lebayon N, Gerard A, Baud JP (2000) Influence of 649 parentage upon growth in Ostrea edulis: evidence for inbreeding depression. Genet $650 \quad$ Res 76:159-168.

651 Naciri Y, Vigouroux Y, Dallas J, Desmarais E, Delsert C, Bonhomme F (1995)

652 Identification and inheritance of $(\mathrm{GA} / \mathrm{TC}) \mathrm{n}$ and $(\mathrm{AC} / \mathrm{GT}) \mathrm{n}$ repeats in the European 653 flat oyster Ostrea edulis (L.). Mol Mar Biol Biotechnol 4:83-89.

654 Nei M (1978) Estimation of Average Heterozygosity and Genetic Distance from a 655 Small Number of Individuals. Genetics 89:583-590.

656 Pullin AS, Knight TM (2009) Doing more good than harm - Building an evidence-base 657 for conservation and environmental management. Biological Conservation 142:931658934.

659 Ryman N, Laikre L (1991) Effects of supportive breeding on the genetically effective 660 population size. Conservation Biology 5:325-329.

661 Saavedra C (1997) Low effective sizes in hatchery populations of the European oyster 662 (Ostrea edulis): Implications for the management of genetic resources. J Shellfish 663 Res 16:441-446.

664 Saavedra C, Guerra A (1996) Allozyme heterozygosity, founder effect and fitness traits 665 in a cultivated population of the European oyster, Ostrea edulis. Aquaculture $666 \quad 139: 203-224$.

667 Sambrook J, Fritsch EF, Maniatis T (1989) Molecular cloning: A laboratory manual. 668 Cold Spring Harbor Laboratory Press, Cold Spring Harbour, New York.

669 Sobolewska H, Beaumont AR (2005) Genetic variation at microsatellite loci in northern 670 populations of the European flat oyster (Ostrea edulis). J Mar Biol Assoc UK $671 \quad 85: 955-960$. 
672 Sobolewska H, Beaumont AR, Hamilton A (2001) Dinucleotide microsatellites isolated 673 from the European flat oyster, Ostrea edulis. Mol Ecol Notes 1:79-80.

674 Soulé ME (1976) Allozyme variation, its determinants in space and time. In: Molecular 675 Evolution (ed. Ayala FJ), pp. 46-59. Sinauer Associates, Sunderland, Massachusetts. 676 Taris N, Batista FM, Boudry P (2007) Evidence of response to unintentional selection 677 for faster development and inbreeding depression in Crassostrea gigas larvae. 678 Aquaculture 272:S69-S79.

679 Taris N, Ernande B, McCombie H, Boudry P (2006) Phenotypic and genetic 680 consequences of size selection at the larval stage in the Pacific oyster (Crassostrea 681 gigas). J Exp Mar Biol Ecol 333:147-158.

682 Wang J (2009) A new method for estimating effective population sizes from a single 683 sample of multilocus genotypes. Mol Ecol 18:2148-2164.

684 Waples RS, Do C (2008) LDNE: a program for estimating effective population size 685 from data on linkage disequilibrium. Mol Ecol Resour 8:753-756.

686 Waples RS, Do C (2009) Linkage disequilibrium estimates of contemporary $N_{e}$ using 687 highly variable genetic markers: a largely untapped resource for applied 688 conservation and evolution. Evol Appl doi:10.1111/j.1752-4571.2009.00104.x. 689 Weir BS, Cockerham CC (1984) Estimating F-statistics for the analysis of population $690 \quad$ structure. Evolution 38:1358-1370.

691 Wilbur AE, Seyoum S, Bert TM, Arnold WS (2005) A genetic assessment of bay 692 scallop (Argopecten irradians) restoration efforts in Florida's Gulf of Mexico 693 Coastal Waters (USA). Conserv Genet 6:111-122.

694 Wright S (1931) Evolution in Mendelian Populations. Genetics 16:97-159. 
Table 1. Genetic diversity summary statistics in twelve populations of Ostrea edulis. $N_{a}$ : number of alleles, $A$ : allelic richness, $H_{o}$ : observed heterozygosity, $H_{e}$ : expected heterozygosity. Significant ( $\mathrm{p}<0.05$ after Bonferroni adjustment) $F_{i s}$ values in bold. For population abbreviations see Figure 1.

\begin{tabular}{|c|c|c|c|c|c|c|c|c|c|c|c|c|c|}
\hline \multirow[t]{2}{*}{ Locus } & & \multicolumn{4}{|c|}{ Wild populations } & \multicolumn{4}{|c|}{ Pond-produced stocks } & \multicolumn{4}{|c|}{ Hatchery-produced stocks } \\
\hline & & WQ & WGr & WLR & WRF & PBo & $\mathrm{PVa}$ & $\mathrm{PVe}$ & PRo & $\mathrm{HO}$ & HLK & HBOR & HMED \\
\hline \multirow[t]{5}{*}{ OeduJ12 } & $N_{a}$ & 21 & 22 & 20 & 18 & 13 & 15 & 16 & 22 & 13 & 7 & 8 & 10 \\
\hline & $A$ & 18.66 & 18.20 & 17.70 & 17.65 & 11.72 & 13.16 & 14.00 & 18.34 & 11.97 & 6.70 & 6.78 & 8.81 \\
\hline & $H_{o}$ & 0.875 & 0.854 & 0.875 & 0.867 & 0.729 & 0.854 & 0.813 & 0.875 & 0.979 & 0.718 & 0.900 & 0.975 \\
\hline & $H_{e}$ & 0.918 & 0.879 & 0.925 & 0.922 & 0.860 & 0.875 & 0.847 & 0.912 & 0.885 & 0.757 & 0.712 & 0.729 \\
\hline & $F_{i s}$ & 0.047 & 0.028 & 0.055 & 0.061 & 0.153 & 0.024 & 0.042 & 0.041 & -0.107 & 0.052 & -0.269 & -0.344 \\
\hline \multirow[t]{5}{*}{ Oedu.B11 } & $N_{a}$ & 32 & 23 & 32 & 27 & 17 & 20 & 21 & 19 & 10 & 7 & 5 & 11 \\
\hline & $A$ & 26.16 & 20.89 & 26.81 & 27.00 & 15.54 & 18.03 & 18.16 & 16.40 & 9.09 & 6.71 & 4.94 & 9.36 \\
\hline & $H_{o}$ & 0.500 & 0.733 & 0.644 & 0.714 & 0.553 & 0.689 & 0.739 & 0.638 & 0.583 & 0.641 & 0.405 & 0.725 \\
\hline & $H_{e}$ & 0.956 & 0.947 & 0.960 & 0.970 & 0.912 & 0.875 & 0.927 & 0.899 & 0.808 & 0.810 & 0.687 & 0.633 \\
\hline & $F_{\text {is }}$ & 0.480 & 0.228 & 0.332 & 0.267 & 0.396 & 0.215 & 0.205 & 0.292 & 0.280 & 0.211 & 0.414 & -0.148 \\
\hline
\end{tabular}




\begin{tabular}{|c|c|c|c|c|c|c|c|c|c|c|c|c|c|}
\hline \multirow[t]{5}{*}{ Oedu.HA7 } & $N_{a}$ & 20 & 22 & 21 & 20 & 16 & 17 & 20 & 18 & 11 & 7 & 9 & 12 \\
\hline & $A$ & 17.45 & 18.48 & 18.73 & 19.46 & 14.64 & 14.90 & 15.83 & 15.93 & 9.54 & 6.44 & 8.05 & 10.28 \\
\hline & $H_{o}$ & 0.979 & 0.937 & 0.937 & 0.967 & 0.937 & 0.896 & 0.958 & 0.875 & 0.896 & 0.872 & 1.000 & 0.875 \\
\hline & $H_{e}$ & 0.935 & 0.919 & 0.932 & 0.933 & 0.906 & 0.866 & 0.885 & 0.909 & 0.805 & 0.780 & 0.792 & 0.773 \\
\hline & $F_{i s}$ & -0.048 & -0.020 & -0.005 & -0.036 & -0.035 & -0.034 & -0.083 & 0.038 & -0.113 & -0.120 & -0.267 & -0.134 \\
\hline \multirow[t]{5}{*}{ Oe3/44 } & $N_{a}$ & 12 & 21 & 16 & 9 & 8 & 11 & 11 & 15 & 5 & 6 & 4 & 7 \\
\hline & $A$ & 10.08 & 16.14 & 12.82 & 8.99 & 7.03 & 9.24 & 9.28 & 11.26 & 4.99 & 5.44 & 3.91 & 5.99 \\
\hline & $H_{o}$ & 0.687 & 0.792 & 0.854 & 0.800 & 0.687 & 0.646 & 0.681 & 0.875 & 0.667 & 0.769 & 0.975 & 0.975 \\
\hline & $H_{e}$ & 0.644 & 0.862 & 0.825 & 0.768 & 0.692 & 0.638 & 0.741 & 0.808 & 0.658 & 0.752 & 0.637 & 0.595 \\
\hline & $F_{i s}$ & -0.069 & 0.082 & -0.035 & -0.042 & 0.007 & -0.012 & 0.082 & -0.084 & -0.013 & -0.023 & -0.542 & -0.652 \\
\hline \multirow[t]{5}{*}{ Oedu T5 } & $N_{a}$ & 22 & 19 & 23 & 19 & 15 & 17 & 18 & 17 & 9 & 7 & 8 & 12 \\
\hline & $A$ & 18.46 & 16.98 & 19.33 & 18.59 & 13.48 & 13.97 & 15.53 & 15.02 & 8.34 & 6.98 & 7.00 & 10.06 \\
\hline & $H_{o}$ & 0.896 & 0.917 & 0.937 & 0.900 & 0.875 & 0.917 & 0.979 & 0.812 & 0.917 & 1.000 & 1.000 & 0.600 \\
\hline & $H_{e}$ & 0.901 & 0.929 & 0.930 & 0.935 & 0.885 & 0.907 & 0.921 & 0.887 & 0.843 & 0.826 & 0.716 & 0.672 \\
\hline & $F_{i s}$ & 0.006 & 0.013 & -0.008 & 0.038 & 0.012 & -0.011 & -0.064 & 0.085 & -0.088 & -0.214 & -0.404 & 0.109 \\
\hline
\end{tabular}




\begin{tabular}{|c|c|c|c|c|c|c|c|c|c|c|c|c|c|}
\hline \multirow[t]{5}{*}{ Overall } & $N_{a}$ & 21.4 & 21.4 & 22.4 & 18.6 & 13.8 & 16.0 & 17.2 & 18.2 & 9.6 & 6.8 & 6.8 & 10.4 \\
\hline & $A$ & 18.16 & 18.14 & 19.08 & 18.34 & 12.48 & 13.86 & 14.56 & 15.39 & 8.79 & 6.45 & 6.14 & 8.90 \\
\hline & $H_{o}$ & 0.788 & 0.847 & 0.850 & 0.850 & 0.756 & 0.800 & 0.834 & 0.815 & 0.808 & 0.800 & 0.856 & 0.830 \\
\hline & $H_{e}$ & 0.871 & 0.907 & 0.915 & 0.906 & 0.851 & 0.832 & 0.864 & 0.883 & 0.800 & 0.785 & 0.709 & 0.680 \\
\hline & $F_{i s}$ & 0.097 & 0.067 & 0.072 & 0.063 & 0.112 & 0.039 & 0.036 & 0.078 & -0.011 & -0.019 & -0.211 & -0.223 \\
\hline Overall & $N_{a}$ & 18.8 & 21.0 & 20.0 & 16.5 & 13.0 & 15.0 & 16.3 & 18.0 & 9.5 & 6.8 & 7.3 & 10.3 \\
\hline (without & $A$ & 16.16 & 17.45 & 17.15 & 16.17 & 11.72 & 12.82 & 13.66 & 15.14 & 8.71 & 6.39 & 6.44 & 8.79 \\
\hline \multirow[t]{3}{*}{ Oedu.B11) } & $H_{o}$ & 0.859 & 0.875 & 0.901 & 0.884 & 0.807 & 0.828 & 0.858 & 0.859 & 0.865 & 0.840 & 0.969 & 0.856 \\
\hline & $H_{e}$ & 0.849 & 0.897 & 0.903 & 0.890 & 0.836 & 0.822 & 0.849 & 0.879 & 0.798 & 0.779 & 0.714 & 0.692 \\
\hline & $F_{i s}$ & -0.012 & 0.025 & 0.003 & 0.007 & 0.035 & -0.008 & -0.016 & 0.023 & -0.084 & -0.079 & -0.363 & -0.241 \\
\hline
\end{tabular}


Table 2. Weir \& Cockerham's (1984) estimator of $F_{s t}$ calculated for each pair of population, based on five microsatellite markers. Significant $\left(\mathrm{p}<0.05\right.$ after Bonferroni adjustment) $F_{s t}$ values in bold. For population abbreviations see Figure 1.

\begin{tabular}{|c|c|c|c|c|c|c|c|c|c|c|c|}
\hline & WQ & WGr & WLR & WRF & PBo & $\mathrm{PVa}$ & $\mathrm{PVe}$ & PRo & $\mathrm{HO}$ & HLK & HBOR \\
\hline $\begin{array}{l}\text { WQ } \\
\end{array}$ & - & & & & & & & & & & \\
\hline WGr & 0.044 & - & & & & & & & & & \\
\hline WLR & 0.031 & 0.006 & - & & & & & & & & \\
\hline WRF & 0.006 & 0.035 & 0.024 & - & & & & & & & \\
\hline PBo & 0.076 & 0.035 & 0.033 & 0.063 & - & & & & & & \\
\hline $\mathrm{PVa}$ & 0.089 & 0.038 & 0.036 & 0.080 & 0.006 & - & & & & & \\
\hline $\mathrm{PVe}$ & 0.072 & 0.010 & 0.021 & 0.059 & 0.036 & 0.040 & - & & & & \\
\hline PRo & 0.036 & 0.032 & 0.019 & 0.021 & 0.061 & 0.071 & 0.057 & - & & & \\
\hline $\mathrm{HO}$ & 0.097 & 0.071 & 0.061 & 0.096 & 0.102 & 0.108 & 0.087 & 0.083 & - & & \\
\hline HLK & 0.109 & 0.083 & 0.069 & 0.108 & 0.106 & 0.114 & 0.105 & 0.107 & 0.095 & - & \\
\hline HBOR & 0.095 & 0.132 & 0.118 & 0.100 & 0.172 & 0.172 & 0.167 & 0.123 & 0.168 & 0.212 & - \\
\hline HMED & 0.142 & 0.149 & 0.129 & 0.126 & 0.146 & 0.160 & 0.158 & 0.141 & 0.206 & 0.217 & 0.254 \\
\hline
\end{tabular}


Table 3. Estimates of effective breeding sizes for O. edulis populations. H excess: heterozygote excess method implemented in Colony v2.0 (Wang 2009); LD: linkage disequilibrium method using LDNE program (Waples and Do 2008); Sibship: sibshipbased estimates using Colony v2.0 (Wang 2009). 95\% confidence intervals are given in brackets. n: sample size; $N_{b}$ : effective breeding size; $\infty$ : infinity.

\begin{tabular}{|c|c|c|c|c|}
\hline \multirow[t]{2}{*}{ Population (n) } & \multicolumn{3}{|c|}{ Effective breeding size estimates $\left(N_{b}\right)$} & \multirow[t]{2}{*}{ Type } \\
\hline & $\mathrm{H}$ excess & LD & Sibship & \\
\hline WQ (48) & $\infty$ & $1130[209-\infty]$ & 54 [34-88] & \multirow{4}{*}{ Wild } \\
\hline WGr (48) & $\infty$ & $13652[246-\infty]$ & 57 [37-92] & \\
\hline WLR (48) & $\infty$ & $\infty[448-\infty]$ & 64 [41-104] & \\
\hline WRF (30) & $\infty$ & $382[80-\infty]$ & $47[28-85]$ & \\
\hline PBo (48) & $\infty$ & $138[74-536]$ & 38 [24-64] & \multirow{4}{*}{ Pond } \\
\hline PVa (48) & $\infty$ & 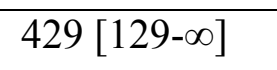 & 40 [26-65] & \\
\hline $\mathrm{PVe}(48)$ & $\infty$ & 33 [26-45] & 24 [13-46] & \\
\hline PRo (48) & $\infty$ & $49[37-70]$ & $38[23-64]$ & \\
\hline $\mathrm{HO}(48)$ & $\infty$ & 19 [14-25] & $18[10-38]$ & \multirow{4}{*}{ Hatchery } \\
\hline HLK (39) & $\infty$ & $4[3-8]$ & $10[5-26]$ & \\
\hline HBOR (40) & 7 & $6[3-10]$ & $12[6-28]$ & \\
\hline HMED (40) & 7 & $2[2-3]$ & $9[4-23]$ & \\
\hline
\end{tabular}


Table 4. Reconstructed genotypes of parents of large full-sibs families identified in the four hatchery-produced populations, using the program PEDIGREE 2.2. n: number of offspring in the full-sibs group; null: null allele segregating in the family; $\mathrm{Chi}^{2}$ : chisquared value for the Mendelian segregation test in the progeny (significant $\mathrm{p}<0.05$ values in bold).

\begin{tabular}{|c|c|c|c|c|}
\hline Population & FS group (n) & Marker & Reconstructed genotype & $\mathrm{Chi}^{2}$ \\
\hline \multirow[t]{5}{*}{ HMED } & \multirow[t]{5}{*}{$1(30)$} & OeduJ12 & $238 / 238 \times 228 / 250$ & 0.00 \\
\hline & & Oedu.B11 & $136 / 136 \times 136 / 148$ & 8.53 \\
\hline & & Oedu.HA7 & $154 / 172 \times 172 / 182$ & 6.80 \\
\hline & & Oe3/44 & $185 / 185 \times 213 / 213$ & 0.00 \\
\hline & & OeduT5 & $118 / 138 \times 118 / 138$ & 1.20 \\
\hline \multirow[t]{5}{*}{ HBOR } & \multirow[t]{5}{*}{$1(30)$} & OeduJ12 & $230 / 234 \times 226 / 230$ & 7.78 \\
\hline & & Oedu.B11 & $122 / 128 \times 166 /$ null & 1.73 \\
\hline & & Oedu.HA7 & $164 / 178 \times 172 / 186$ & 2.44 \\
\hline & & Oe3/44 & $185 / 185 \times 205 / 215$ & 5.56 \\
\hline & & OeduT5 & $134 / 134 \times 126 / 144$ & 0.00 \\
\hline \multirow[t]{5}{*}{ HLK } & \multirow[t]{5}{*}{$1(18)$} & OeduJ12 & $236 / 244 \times 244 / 248$ & 2.44 \\
\hline & & Oedu.B11 & $142 /$ null x $134 / 148$ & 0.67 \\
\hline & & Oedu.HA7 & $162 / 172 \times 174 / 178$ & 4.22 \\
\hline & & Oe3/44 & $205 / 217 \times 209 / 217$ & 1.11 \\
\hline & & OeduT5 & $124 / 134 \times 138 / 146$ & 2.00 \\
\hline
\end{tabular}


Table 5. Reconstruction of parental genotypes at locus Oedu.B11, compatible with the segregation of a null allele. 1: output of the software PEDIGREE 2.2 (Herbinger et al. 2006); 2: interpretation of the results based on the existence of null alleles at the locus.

\begin{tabular}{|c|c|c|c|c|}
\hline \multirow{6}{*}{ HBOR } & \multirow[t]{2}{*}{1} & & \multicolumn{2}{|l|}{ Group 1 (18 offspring) } \\
\hline & & Parents genotypes & $\begin{array}{c}122 / 122 \times 122 / 166 \\
\downarrow\end{array}$ & $\begin{array}{r}128 / 128 \times 128 / 166 \\
\downarrow\end{array}$ \\
\hline & & Progeny genotypes & $122 / 166,122 / 122$ & $128 / 166,128 / 128$ \\
\hline & \multirow[t]{3}{*}{2} & & \multicolumn{2}{|c|}{ Pooled family (30 offspring) } \\
\hline & & Parents genotypes & \multicolumn{2}{|c|}{$122 / 128$ x 166/null } \\
\hline & & Progeny genotypes & \multicolumn{2}{|c|}{$122 / 166,128 / 166,122 /$ null, $128 /$ null } \\
\hline \multirow{6}{*}{ HLK } & \multirow[t]{3}{*}{1} & & Group 1 (10 offspring) & Group 2 (4 offspring) \\
\hline & & Parents genotypes & $\begin{array}{c}134 / 148 \times 142 / 148 \\
\downarrow\end{array}$ & $\begin{array}{c}134 / 134 \times 134 / 134 \\
\downarrow\end{array}$ \\
\hline & & Progeny genotypes & $134 / 142,142 / 148,148 / 148$ & $134 / 134$ \\
\hline & \multirow[t]{3}{*}{2} & & \multicolumn{2}{|c|}{ Pooled family (14 offspring) } \\
\hline & & Parents genotypes & \multicolumn{2}{|c|}{$134 / 148 \times 142 /$ null } \\
\hline & & Progeny genotypes & \multicolumn{2}{|c|}{$134 / 142,142 / 148,134 /$ null, $148 /$ null } \\
\hline
\end{tabular}


Fig. 1 Sample sites of Ostrea edulis. WQ: Quiberon (Brittany, France), WLR: Loch Ryan (Scotland), WRF: Ria Formosa (Portugal), WGr: Grevelingen (the Netherlands); PRo: Rossmore (Ireland), PVe: Venø, Struer (Denmark), PBo: Boemlo (Norway), PVa: Vaagstranda (Norway); HLK (Loch Kishorn, UK, commercial hatchery); HO (Orkney, UK, commercial hatchery); HBOR (Brittany, France, research hatchery) and HMED (Mediterranean, research hatchery, France)

Fig. $2 N_{b}$ estimates and allelic richness for 12 O. edulis populations. LD: $N_{b}$ estimates based on the linkage disequilibrium method. SA: $N_{b}$ estimates based on the sibship assignment method. Upper $X$ axis for SA estimates, lower $X$ axis for LD estimates. Straight line: regression for LD estimates of $N_{b}$; dotted line: regression for SA estimates of $N_{b}$.

Fig. 3 Distributions of individuals from the four hatchery-produced populations into fullsib (FS) groups using the program PEDIGREE 2.2 (Herbinger et al. 2006). Each vertical bar represents a FS group. The output of the program has been modified for the populations HBOR and HLK due to evidence of null alleles (see 3.5. and Table 5) 
Click here to download high resolution image

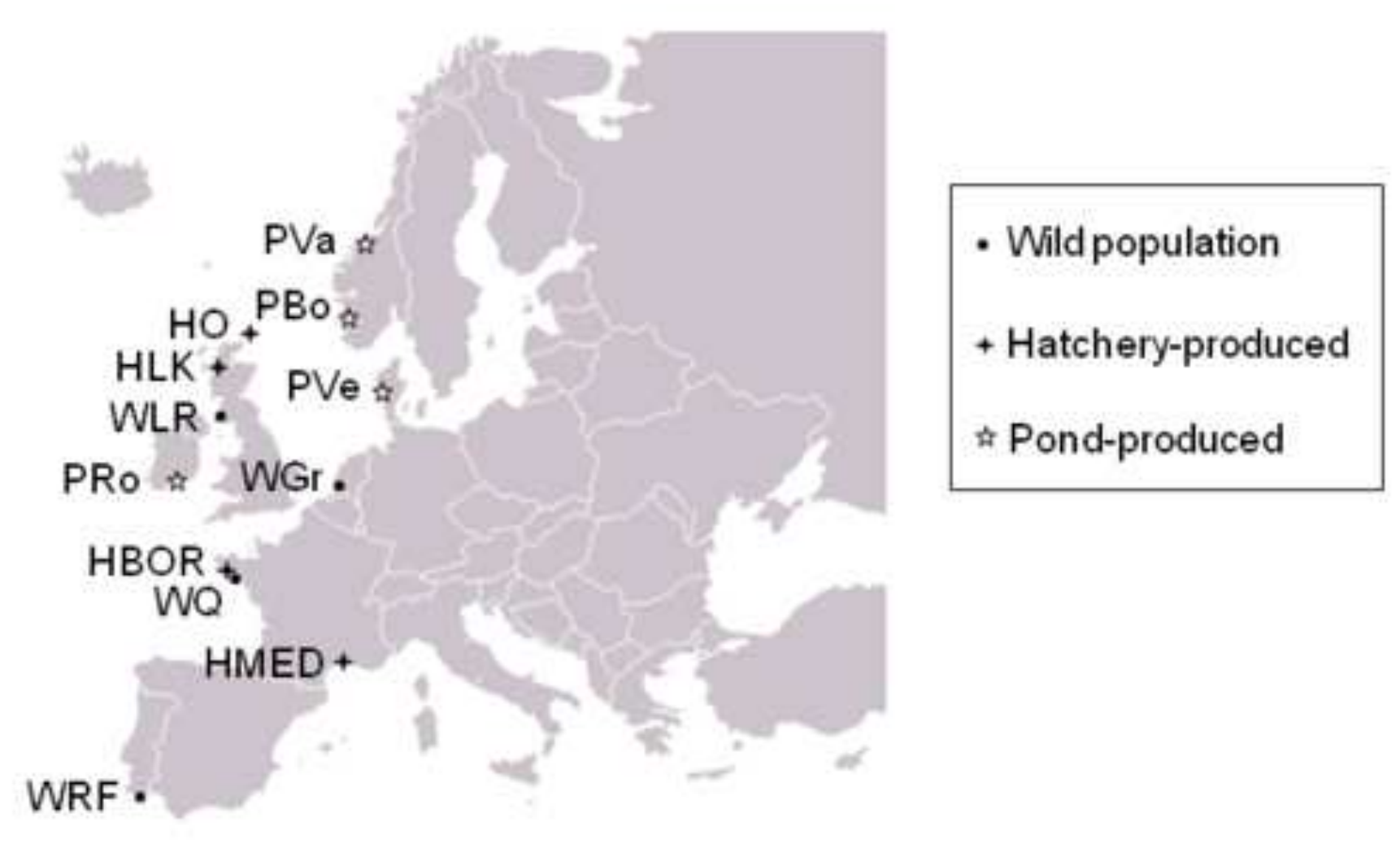

WRF 。

- Wild population

Hatchery-produced

Pond-produced

\section{$\mathrm{BBOR}$}

WQ

HMED +

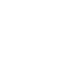


Click here to download high resolution image

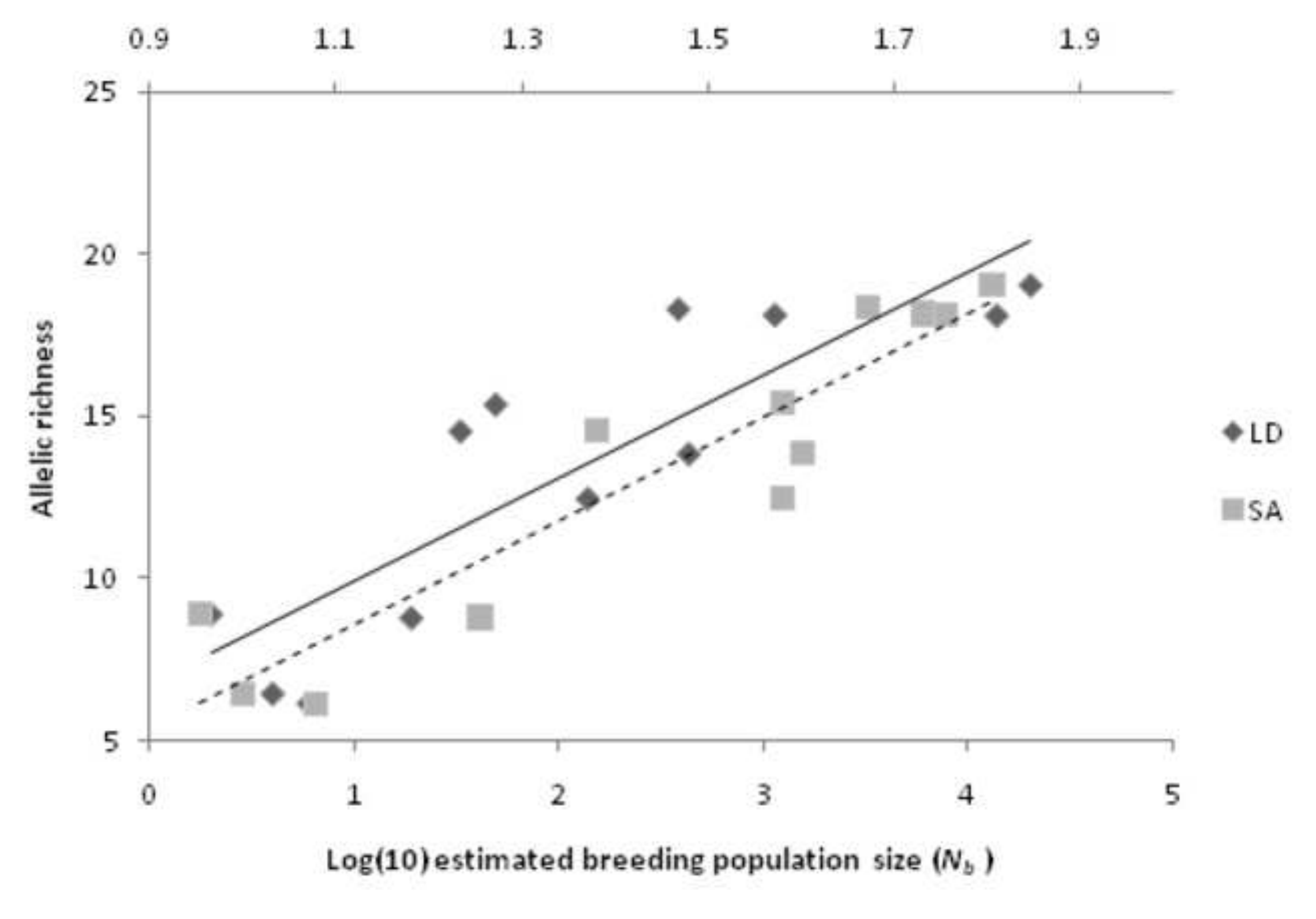

line figure 
Click here to download high resolution image

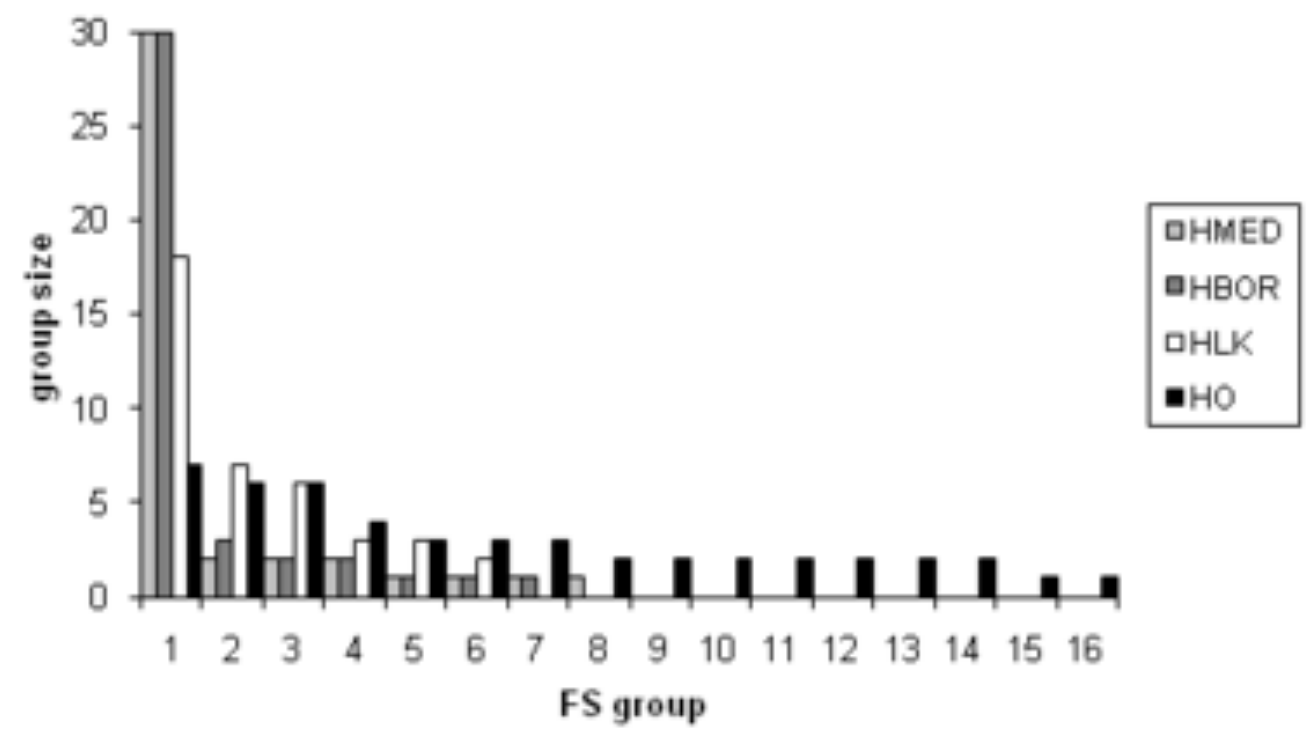

